\title{
Gangguan Pendengaran dan Keseimbangan pada Penderita Tuberkulosis yang Mendapat Pengobatan Antituberkulosis Kategori 1 dan 2
}

\section{Hearing and Balance Impairment in Tuberculosis Patient with Category $1^{\text {st }}$ and $2^{\text {nd }}$ Antituberculosis Treatment}

\author{
Indri Adriztina* Adlin Adnan* Siti Hajar Haryuna* Parluhutan Siagian** Sorimuda Sarumpaet***
}

\begin{abstract}
*Bagian Ilmu Kesehatan Telinga Hidung Tenggorok-Bedah Kepala Leher FK USU, **Departemen Pulmonologi dan Ilmu Kedokteran Respirasi FK USU, ***Epi-Treat Unit, Lembaga Pengabdian Masyarakat USU
\end{abstract}

\begin{abstract}
Abstrak
Tuberkulosis merupakan masalah yang serius di masyarakat. Pada tahun 2010, World Health Organization mencatat jumlah penderita tuberkulosis di Indonesia menurun ke posisi empat dengan meningkatnya keberhasilan pengobatan obat antituberkulosis (OAT). Namun, pemberian OAT jangka panjang dapat menyebabkan efek samping ototoksik berupa gangguan pendengaran dan keseimbangan. Penelitian ini dilakukan untuk mengetahui efek ototoksik pada penderita tuberkulosis paru dengan pemberian OAT di RSUP H. Adam Malik Medan. Penelitian ini bersifat deskriptif dengan pendekatan potong lintang. Analisis univariat dilakukan dengan tabel frekuensi distribusi sedangkan analisis bivariat dilakukan dengan menggunakan uji t dan Fisher's exact test. Didapatkan 35 penderita tuberkulosis yang memenuhi kriteria inklusi, 22 orang dengan pengobatan tuberkulosis kategori 1 dan 13 orang tuberkulosis kategori 2 . Dilakukan pemeriksaan audiometri nada murni dan tes keseimbangan. Tiga orang $(33,3 \%)$ penderita tuberkulosis kategori 1 dan 6 orang $(66,7 \%)$ penderita tuberkulosis kategori 2 mengalami gangguan pendengaran $(p<0,05)$. Hasil tes keseimbangan menunjukkan perbedaan yang signifikan yaitu 7 orang (100\%) tuberkulosis kategori 2 dengan positif tes Romberg dan 11 orang (100\%) tuberkulosis kategori 2 positif tes tandem Romberg. Gangguan pendengaran dan keseimbangan pada penderita tuberkulosis paru dengan OAT ditemukan lebih tinggi pada kategori 2 dibandingkan dengan kategori 1 dengan perbedaan yang signifikan.

Kata kunci: Tuberkulosis, obat antituberkulosis, gangguan pendengaran
\end{abstract}

\section{Abstract}

Tuberculosis remains a serious problem in the community. In 2010, World Health Organization report that Indonesia's ranking decrease to fourth position due to success of antituberculosis treatment. But the long term administration of antituberculosis treatment may cause ototoxic effect like hearing and balance impairment. The aim of this study was to describe ototoxic effect of subjects who were given tuberculosis treatment in $\mathrm{H}$. Adam
Malik General Hospital. This is a descriptive study with cross sectional approach. Univariat analysis was done by frequency distribution table, meanwhile bivariat analysis was done by t-test and Fisher's exact test. Thirty five pulmonary tuberculosis patients met the inclusion criteria. Twenty two patients with $1^{\text {st }}$ category, and 13 patients with $2^{\text {nd }}$ category tuberculosis treatment. Pure tone audiometric and balance examination was evaluated. Three patients $(33.3 \%)$ of $1^{\text {st }}$ category tuberculosis and $6(66.7 \%)$ patients of $2^{\text {nd }}$ category tuberculosis have hearing loss with significant difference $(p<0.05)$. Balance test showed 7 people $(100 \%)$ of $2^{\text {nd }}$ category tuberculosis having positive Romberg test and 11 people (100\%) of $2^{\text {nd }}$ category tuberculosis having positive tandem Romberg test. Hearing and balance impairment found higher in patients with $2^{\text {nd }}$ category antituberculosis treatment with significantly different.

Keywords: Tuberculosis, antituberculosis treatment, hearing impairment

\section{Pendahuluan}

Tuberkulosis masih merupakan masalah yang serius di masyarakat. Berbagai penelitian epidemiologi menunjukkan adanya kecenderungan peningkatan angka insidensi dan prevalensi tuberkulosis di berbagai penjuru dunia. Menurut data dari World Health Organization (WHO), terjadi peningkatan angka insidensi tuberkulosis paru di Afrika, daerah timur Mediterania dan Asia. Pada tahun 2009, diperkirakan terdapat 9,4 juta kasus baru tuberkulosis di seluruh dunia dan 1,7 juta meninggal karenanya. ${ }^{1}$ Berdasarkan data pada tahun 2007 , jumlah penderita tuberkulosis di Indonesia sekitar 10\% dari seluruh penderita tuberkulosis di dunia atau berada di posisi tiga

Alamat Korespondensi: Indri Adriztina, Bagian Ilmu Kesehatan THT-Bedah Kepala Leher FK USU, Gd. Poli THT-KL Lt. IV RSUP H. Adam Malik Jl. Bunga Lau No.17 Medan, Hp.08126358349, e-mail: adriztina@yahoo.com 
di dunia setelah India dan Cina. Selanjutnya pada tahun 2010, WHO mencatat peringkat Indonesia menurun ke posisi empat setelah India, Cina, dan Afrika Selatan dengan jumlah penderita tuberkulosis sebesar 0,37 juta 0,54 juta orang. 2,3

Di Indonesia, survei prevalensi yang dilaporkan pada tahun 2004 secara nasional pada responden suspek tuberkulosis terhadap penderita dengan umur $\geq 15$ tahun berdasarkan pemeriksaan sputum BTA positif adalah 104 per 100.000 (95\% CI:66 sampai 142 per 100.000). Sedangkan prevalensi tuberkulosis menurut kawasan wilayah di Indonesia didapati hasil yang beragam. Prevalensi tuberkulosis kawasan Indonesia Timur (189 per 100.000) lebih tinggi dibandingkan Sumatera (160 per 100.000), sedangkan prevalensi tuberkulosis di JawaBali jauh lebih rendah (59 per 100.000). Sementara itu, berdasarkan data dari Kementerian Kesehatan Republik Indonesia pada tahun 2011, angka kejadian tuberkulosis paru kategori 2, berkisar 10\% dari jumlah pasien tuberkulosis yang diterapi di rumah sakit umum, rumah sakit paru dan balai paru kesehatan masyarakat (BPKM/BP4) pada tahun 2006-2007. Sedangkan pada penelitian yang dilakukan di Poli Paru RS Persahabatan Jakarta, terdapat 5,3\% pasien yang diterapi sesuai dengan pengobatan kategori 2 dari seluruh jumlah pasien tuberkulosis pada periode Januari sampai Juli 2005.4,5

Pengobatan tuberkulosis bertujuan untuk menyembuhkan pasien, mencegah kematian, mencegah kekambuhan, memutuskan rantai penularan, dan mencegah terjadinya resistensi kuman terhadap obat antituberkulosis (OAT). Namun pemberian OAT seperti rifampisin (R), isoniazid $(\mathrm{H})$, pirazinamid $(\mathrm{Z})$, etambutol $(\mathrm{E})$, dan streptomisin (S) yang lazim digunakan, dilaporkan dapat memberikan efek samping pada pemberian dalam jangka panjang. Streptomisin, OAT golongan aminoglikosida yang hanya diberikan pada penderita tuberkulosis paru kategori 2, merupakan OAT yang paling sering dilaporkan menyebabkan gangguan pendengaran dan gangguan keseimbangan. Hal ini disebabkan oleh efek kokleotoksik dan vestibulotoksik. Sebuah penelitian oleh Lima et al, 6 tentang gambaran gangguan pendengaran pada 36 pasien penderita tuberkulosis di Recife, Brazil pada tahun 2000-2001 yang diberi pengobatan streptomisin, didapati 27 penderita $(75 \%)$ mengalami gangguan pendengaran. Selaras dengan penelitian tersebut, Vasconselos, ${ }^{1}$ dalam penelitiannya melaporkan bahwa terjadi perbedaan yang signifikan terhadap gangguan ambang dengar penderita tuberkulosis dengan pemakaian obat golongan aminoglikosida dibandingkan dengan yang tidak $(p=0,034)$. Namun, hasil yang berbeda dilaporkan oleh Ahmed et al, ${ }^{7}$ dalam penelitiannya mendapatkan dari 103 orang $(100 \%)$ dengan gangguan keseimbangan akibat pemakaian obat aminoglikosida hanya 3 orang $(2,9 \%)$ yang menderita gangguan pendengaran.
Pada pemberian isoniazid dan ethambutol, meskipun dapat menyebabkan gangguan terhadap sistem saraf perifer, kelemahan sistem motorik dan gangguan sensori, tetapi sampai saat ini angka kejadian ototoksik pada pemberian obat-obatan jenis ini masih sedikit dilaporkan. Penelitian terhadap 40 orang pasien gagal ginjal kronis dengan hemodialisa dengan terapi tuberkulosis tanpa pemberian streptomisin mendapati $7(16,6 \%)$ kasus menderita gangguan pendengaran, dua diantaranya membaik setelah pemberian isoniazid dihentikan. Dilaporkan 2 pasien tuberkulosis yang menjalani terapi hemodialisa menderita gangguan pendengaran setelah pemberian isoniazid. $8,9,10$

Informasi tentang gambaran efek gangguan pendengaran dan keseimbangan penderita tuberkulosis masih sulit tersedia bahkan sampai saat ini belum didapatkan data yang pasti di RSUP H. Adam Malik Medan. Tujuan penelitian ini untuk mengetahui gambaran gangguan pendengaran dan keseimbangan pada penderita tuberkulosis dengan pengobatan kategori 1 dan kategori 2 di Rumah Sakit Umum Pusat H. Adam Malik Medan.

\section{Metode}

Penelitian ini bersifat deskriptif dengan pendekatan potong lintang melalui pengumpulan data primer yang diambil dari pasien tuberkulosis paru yang datang berobat ke RSUP H. Adam Malik Medan. Penelitian dilakukan di Departemen/SMF THT-KL dan Departemen Pulmonologi Fakultas Kedokteran Universitas Sumatera Utara (FK USU) RSUP H. Adam Malik Medan mulai April - Oktober 2012 dan telah disetujui oleh Komite Etik Penelitian Bidang Kesehatan, Fakultas Kedokteran Universitas Sumatera Utara. Sampel terdiri dari 35 orang pasien yang berobat ke Departemen Pulmonologi FK USU RSUP H. Adam Malik Medan dengan diagnosis tuberkulosis paru yang menggunakan obat antituberkulosis dan berusia 18-60 tahun. Pengobatan tuberkulosis paru yang diikutsertakan pada penelitian ini adalah pengobatan tuberkulosis kategori 1 yang menggunakan regimen rifampisin, isoniazid, etambutol, dan pirazinamid, serta tuberkulosis kategori 2 dengan penambahan regimen streptomisin. Penderita yang telah mendapatkan injeksi streptomisin atau golongan aminoglikosida lain sebelumnya atau mendapatkan terapi lain yang juga bersifat ototoksik (furosemid, cisplatin, hemodialisa), menderita penyakit lain yang dapat mengakibatkan gangguan pendengaran (diabetes melitus, gagal ginjal, hipertensi, dll), dengan gangguan telinga lain pada pemeriksaan THT rutin dan dengan gangguan tuli konduktif dari hasil pemeriksaan audiometri tidak diikutsertakan dalam penelitian ini.

Pasien dengan pemeriksaan THT rutin normal kemudian diperiksa ada tidaknya gangguan pendengaran dengan menilai gambaran audiometri (audiometer audio 
traveller AA222). Pemeriksaan audiometri dilakukan pada frekuensi $250 \mathrm{~Hz}, 500 \mathrm{~Hz}, 1000 \mathrm{~Hz}, 2000 \mathrm{~Hz}, 3000$ $\mathrm{Hz}, 4000 \mathrm{~Hz}, 6000 \mathrm{~Hz}$, dan $8000 \mathrm{~Hz}$. Ambang dengar dihitung dengan menggunakan indeks Fletcher dan dibagi menjadi normal $(0-<25 \mathrm{~dB})$, tuli ringan $(26-40 \mathrm{~dB})$, tuli sedang (41-55 dB), tuli sedang berat (56-70 dB), tuli berat (71-90 dB) dan tuli sangat berat ( $>90 \mathrm{~dB}$ ). Untuk pemeriksaan keseimbangan dilakukan dengan peneriksaan tes Romberg dan tandem Romberg. Analisis univariat dilakukan secara tabulasi silang dan dilanjutkan dengan tabel frekuensi distribusi. Analisis bivariat dengan menggunakan uji $\mathrm{t}$ dan nilai audiometri diuji dengan uji Fisher's exact test untuk melihat perbedaan nilai audiometri.

\section{Hasil}

Penelitian ini terdiri dari 35 pasien yang telah didiagnosis tuberkulosis paru dan telah mendapatkan pengobatan tuberkulosis kategori 1 dan kategori 2. Penderita tuberkulosis paru yang terbanyak adalah kategori 1 (22;

Tabel 1. Distribusi Proporsi Kategori Pengobatan Tuberkulosis Berdasarkan Kelompok Umur dan Jenis Kelamin

\begin{tabular}{llllll}
\hline \multirow{2}{*}{ Karakteristik } & \multirow{3}{c}{ Kategori Tuberkulosis } \\
\cline { 3 - 5 } & & \multicolumn{2}{c}{ Kategori 1 } & \multicolumn{2}{c}{ Kategori 2 } \\
\cline { 3 - 6 } & & $\mathbf{n}$ & $\%$ & $\mathbf{n}$ & $\%$ \\
\hline \multirow{2}{*}{ Kelompok umur } & $18-40$ tahun & 16 & 72,7 & 8 & 61,5 \\
Jenis kelamin & $41-60$ tahun & 6 & 27,3 & 5 & 38,5 \\
& Laki-laki & 10 & 45,5 & 9 & 69,2 \\
& Perempuan & 12 & 54,5 & 4 & 30,8 \\
\hline
\end{tabular}

Tabel 2. Hubungan Antara Kategori Pengobatan Tuberkulosis Paru dengan Gangguan Pendengaran

\begin{tabular}{llllll}
\hline & \multicolumn{3}{c}{ Gangguan Pendengaran } & \\
\cline { 2 - 5 } Kategori Tuberkulosis & \multicolumn{2}{c}{ Positif (+) } & \multicolumn{2}{c}{ Negatif (-) } & Nilai p \\
\cline { 2 - 5 } & $\mathbf{n}$ & $\%$ & $\mathbf{n}$ & $\%$ & \\
\hline TB paru kategori I & 3 & 33,3 & 19 & 73,0 & \\
TB paru kategori II & 6 & 66,7 & 7 & 27,0 & 0,043 \\
\hline Total & $\mathbf{9}$ & $\mathbf{1 0 0}$ & $\mathbf{2 6}$ & $\mathbf{1 0 0}$ & \\
\hline
\end{tabular}

$62,8 \%)$ sedangkan kategori $2(13 ; 37,2 \%)$. Jenis kelamin penderita tuberkulosis kategori 1 terbanyak ialah perempuan $(12 ; 54,5 \%)$ dan tuberkulosis kategori 2 terbanyak adalah laki-laki (9; 69,2\%). Kelompok umur terbanyak menderita tuberkulosis dengan pengobatan kategori 1 dan kategori 2 adalah kelompok umur 18-40 tahun masing-masing 16 orang $(72,2 \%)$ dan 8 orang $(61,5 \%)$ (Tabel 1).

Gangguan pendengaran yang paling banyak ditemukan adalah pada tuberkulosis dengan pengobatan kategori 2 yaitu 6 orang $(66,7 \%)$. Uji Fisher's exact menunjukkan perbedaan yang signifikan antara kategori pengobatan tuberkulosis dan gangguan pendengaran dengan nilai $\mathrm{p}=0,043$ (Tabel 2). Penderita tuberkulosis dengan ambang dengar normal ditemukan paling banyak pada kategori $1(19 ; 73,1 \%)$, sedangkan derajat gangguan ringan ditemukan paling banyak pada kategori 2 (5; $62,5 \%)$. Pada derajat sedang hanya didapatkan 1 orang $(100 \%)$ yaitu tuberkulosis kategori 2 dan tidak ditemukan derajat sedang berat, berat ataupun sangat berat (Tabel 3).

Dengan menggunakan Fisher's exact test ditemukan hubungan yang signifikan antara kelompok kategori pengobatan tuberkulosis dengan hasil pemeriksaan tes Romberg (nilai $\mathrm{p}=0,000$ ) dan tes tandem Romberg (nilai $\mathrm{p}=0,000$ ) (Tabel 4 dan Tabel 5). Dengan uji t terlihat bahwa terdapat perbedaan yang signifikan antara rerata ambang dengar kelompok pengobatan tuberkulosis kategori 1 dan tuberkulosis kategori 2 pada frekuensi 8000 $\mathrm{Hz}$ (nilai $\mathrm{p}=0,006$ ) (Tabel 6).

\section{Pembahasan}

Kelompok umur penderita tuberkulosis paru kategori 1 yang lebih banyak ditemukan adalah kelompok umur 18-40 tahun yaitu sebanyak 16 orang $(72,7 \%)$, begitu juga dengan penderita tuberkulosis paru kategori 2 yang lebih banyak pada kelompok umur 18-40 tahun yaitu 8 orang $(38,5 \%)$. Namun, tidak ditemukan perbedaan yang signifikan antara kelompok umur dengan kategori pengobatan tuberkulosis paru dinilai dengan uji Fisher's Exact (nilai $\mathrm{p}=0,374$ ). Hasil penelitian ini sesuai dengan penelitian sebelumnya, penderita tuberkulosis paling

Tabel 3. Distribusi Proporsi Derajat Gangguan Pendengaran Penderita Tuberkulosis Paru Berdasarkan Kategori Pengobatan.

\begin{tabular}{|c|c|c|c|c|c|c|}
\hline \multirow{3}{*}{$\begin{array}{l}\text { Kategori } \\
\text { Tuberkulosis }\end{array}$} & \multicolumn{6}{|c|}{ Derajat Gangguan Ambang Dengar } \\
\hline & \multicolumn{2}{|c|}{ Normal } & \multicolumn{2}{|c|}{ Ringan } & \multicolumn{2}{|c|}{ Sedang } \\
\hline & $\mathbf{n}$ & $\%$ & $\mathbf{n}$ & $\%$ & $\mathbf{n}$ & $\%$ \\
\hline TB kategori I & 19 & 73,1 & 3 & 37,5 & 0 & 0 \\
\hline TB kategori II & 7 & 26,9 & 5 & 62,5 & 1 & 100 \\
\hline Total & 26 & 100 & 8 & 100 & 1 & 100 \\
\hline
\end{tabular}


banyak adalah pada usia 40 tahun. Penelitian lain juga menyatakan rerata umur tersering penderita tuberkulosis secara umum adalah 32 tahun. Manzies, ${ }^{11}$ menyatakan bahwa $75 \%$ dari penderita tuberkulosis baru dengan pengobatan kategori 1 paling banyak terdapat pada kelompok umur produktif yaitu 15-54 tahun. Sementara rerata umur penderita tuberkulosis paru kategori 2 terbanyak adalah 38 tahun. $1,6,10$

Pada anak usia dini, bentuk penyebaran penyakit yang umum terjadi merupakan tuberkulosis milier dan meningitis tuberkulosis. Dengan bertambah usia, gambaran ini menjadi kurang umum, hal ini diakibatkan oleh sistem kekebalan tubuh yang berubah pada saat remaja. Tuberkulosis pada tahap ini menunjukkan gambaran yang disebut tipe dewasa (sebelumnya disebut pascaprimer tuberkulosis), ciri khas gambaran yang terjadi adalah kerusakan jaringan dan kavitasi paru-paru. Setelah usia remaja, terdapat peningkatan angka kejadi-

Tabel 4. Hubungan Kategori Pengobatan Tuberkulosis dengan Pemeriksaan Tes Romberg

\begin{tabular}{|c|c|c|c|c|c|}
\hline \multirow{3}{*}{ Kategori Tuberkulosis } & \multicolumn{4}{|c|}{ Pemeriksaan Fungsi Keseimbangan } & \multirow{3}{*}{ Nilai $p$} \\
\hline & \multicolumn{2}{|c|}{ Tes Romberg (+) } & \multicolumn{2}{|c|}{ Tes Romberg (-) } & \\
\hline & $\mathbf{n}$ & $\%$ & $\mathbf{n}$ & $\%$ & \\
\hline TB paru kategori I & 0 & 0,0 & 22 & 78,5 & \\
\hline TB paru kategori II & 7 & 100,0 & 6 & 21,5 & 0,000 \\
\hline Total & 7 & 100,0 & 28 & 100,0 & \\
\hline
\end{tabular}

an tuberkulosis pada usia 20-30 tahun. Perbedaan angka kejadian sesuai dengan umur diakibatkan oleh respons terhadap infeksi akibat perubahan sistem kekebalan tubuh dan gambaran klinis terhadap penyakit tersebut. ${ }^{12}$ Jenis kelamin penderita tuberkulosis paru kategori 1 terbanyak ditemukan adalah perempuan $(12 ; 54,5 \%)$. Sesuai dengan penelitian terdahulu, mendapati jenis kelamin yang terbanyak pada penderita tuberkulosis adalah perempuan $(38 ; 63 \%)$. Hal ini mungkin berhubungan dengan teori bahwa wanita pada usia reproduktif mempunyai progresivitas penyakit yang lebih tinggi dibandingkan dengan laki-laki pada umur yang sama. 10,13

Pada Tabel 1 juga ditunjukkan penderita tuberkulosis paru kategori 2, jenis kelamin yang terbanyak adalah laki-laki $(9 ; 69,2 \%)$. Namun, tidak ditemukan perbedaan yang signifikan antara jenis kelamin dengan kategori pengobatan tuberkulosis paru dinilai dengan uji Fisher's Exact (nilai $\mathrm{p}=0,156$ ). Hasil penelitian ini sesuai dengan penelitian sebelumnya, penderita tuberkulosis paru kategori 2 terbanyak adalah laki-laki.1,6 Perbedaan antara perempuan dan laki-laki pada sistem imunitas dapat menjadi salah satu alasan yang menyebabkan perbedaan gejala, tanda, bentuk, dan hasil pengobatan dari tuberkulosis. Sistem imun terhadap penyakit tuberkulosis dapat berhubungan dengan konsentrasi hormon non-sexsteroid dan sex-steroid. Penelitian yang dilakukan pada hewan memperlihatkan peningkatan aktivitas $\mathrm{Th}_{2}(\mathrm{~T}$ helper $_{2}$ ) pada kehamilan. Namun, disebabkan oleh kurangnya penelitian pada masalah ini, fakta tersebut masih

Tabel 5. Hubungan Kategori Pengobatan Tuberkulosis dengan Pemeriksaan Tes Tandem Romberg

\begin{tabular}{lccccc}
\hline & \multicolumn{4}{c}{ Pemeriksaan Fungsi Keseimbangan } \\
\cline { 2 - 5 } Kategori & \multicolumn{4}{c}{ Tes Tandem Romberg (+) } & \multicolumn{2}{c}{ Tes Tandem Romberg (-) } & Nilai p \\
\cline { 2 - 5 } Tuberkulosis & $\mathbf{n}$ & $\%$ & $\mathbf{n}$ & $\%$ & \\
\hline TB paru kategori I & 0 & 0,0 & 22 & 91,7 \\
TB paru kategori II & 11 & 100 & 2 & 8,3 & \\
\hline Total & $\mathbf{1 1}$ & $\mathbf{1 0 0}$ & $\mathbf{2 4}$ & $\mathbf{1 0 0}$ \\
\hline
\end{tabular}

Tabel 6. Distribusi Rerata Ambang Dengar Penderita Tuberkulosis Sesuai Kategori Pengobatan Berdasarkan Frekuensi Audiometri

\begin{tabular}{cccccc}
\hline & \multicolumn{3}{c}{ Rerata Ambang Dengar Pasien Tuberkulosis } \\
\cline { 2 - 4 } Frekuensi Audiometri (Hz) & \multicolumn{2}{c}{ Kategori 1 } & \multicolumn{2}{c}{ Kategori 2} & \multirow{2}{*}{ p (t-test) } \\
\cline { 2 - 4 } & Mean & SD & Mean & SD & \\
\hline 250 & 22,50 & 4,009 & 25,38 & 3,798 & 0,451 \\
500 & 20,00 & 5,345 & 23,46 & 5,547 & 0,664 \\
1000 & 18,18 & 6,463 & 22,69 & 6,957 & 0,83 \\
2000 & 18,86 & 7,389 & 24,62 & 12,659 & 0,67 \\
4000 & 16,82 & 9,946 & 28,85 & 15,021 & 0,310 \\
8000 & 13,64 & 9,902 & 31,54 & 17,367 & 0,006 \\
\hline
\end{tabular}

Keterangan: SD = Standar Deviasi 
membutuhkan penelitian lebih lanjut. ${ }^{14}$

Penderita tuberkulosis paru kategori 1 lebih banyak yang tidak menderita gangguan pendengaran (19; $86,3 \%$ ) dan pada penderita dengan pemberian obatobatan kategori 2 lebih banyak yang tidak mengalami gangguan pendengaran $(7 ; 53,8 \%)$. Pada uji Fisher's exact test ditemukan perbedaan yang signifikan antara efek gangguan pendengaran dengan kategori pengobatan penderita tuberkulosis (nilai $\mathrm{p}<0,05$ ). Hasil yang serupa dilaporkan pada penelitian lain, perbedaan yang signifikan pada penderita tuberkulosis dengan pemberian pengobatan dengan aminoglikosida dan yang tidak diberikan aminoglikosida (nilai $\mathrm{p}=0,034$ ). Lima, ${ }^{6}$ menemukan $75 \%$ dari penderita tuberkulosis dengan pemberian obatobatan golongan aminoglikosida menderita gangguan pendengaran. ${ }^{1}$ Hal tersebut mungkin disebabkan oleh efek kokleotoksik yang merupakan salah satu efek samping dari aminoglikosida. Aminoglikosida dapat merusak sel rambut pada telinga dalam dengan berbagai mekanisme seperti menginduksi jalur kematian sel ataupun reaksi oksidatif. Mekanisme ini dapat terlihat dengan gejala klinis berupa gangguan pendengaran yang dinilai dari hasil pemeriksaan audiometri. ${ }^{15,16}$

Pada penelitian ini, penderita tuberkulosis paru paling banyak dengan derajat ambang dengar normal adalah 26 orang $(100 \%)$ yang terdiri dari 19 orang dengan pengobatan tuberkulosis kategori 1 dan 7 orang dengan pengobatan tuberkulosis kategori 2. Hal yang sama dilaporkan pada penelitian lain yang tidak menemukan gangguan ototoksik pada penderita tuberkulosis dengan pengobatan kategori 1.17 Efek ototoksik dari obat-obatan tuberkulosis paru kategori 1 memang belum banyak dilaporkan pada penelitian-penelitian sebelumnya. Banyaknya penderita dengan pendengaran normal diakibatkan karena pada penelitian ini penderita tuberkulosis paru kategori 1 kelompok umur 18 - 40 tahun merupakan sampel yang paling banyak didapati. Pada penderita tuberkulosis paru usia muda diketahui bahwa efek ototoksik yang terjadi dapat diminimalisir dengan fungsi ginjal yang baik. ${ }^{18}$

Derajat gangguan pendengaran yang paling banyak terjadi adalah derajat ringan yaitu sebanyak 8 orang, 5 orang $(62,5 \%)$ diantaranya merupakan kelompok tuberkulosis kategori 2. Sedangkan tidak ditemukan satu orang pun menderita derajat gangguan sedang berat, berat, dan sangat berat. Hal ini sejalan dengan penelitian yang dilakukan oleh Vasconcelos, ${ }^{1}$ yang menyatakan pada kelompok umur 18-40 tahun hanya 44\% yang mengalami gangguan nilai audiometri sedangkan sisanya normal. Sama halnya dengan penelitian yang dilakukan oleh Javadi et al, ${ }^{19}$ yang mendapatkan derajat gangguan pendengaran yang paling banyak terjadi akibat pemberian aminoglikosida adalah pada derajat ringan yaitu sebesar $44,83 \% .{ }^{1}$ Gangguan pendengaran yang terjadi sebagian besar hanya pada derajat ringan. Hal ini disebabkan oleh gangguan pendengaran akibat obat ototoksik diawali pada frekuensi tinggi, sedangkan pada frekuensi rendah dapat ditemukan normal sehingga tidak terlalu mempengaruhi nilai derajat ambang dengar. ${ }^{6,20}$ Efek samping terbesar pada pemberian streptomisin adalah patologi vestibular dengan gejala klinis gangguan keseimbangan. Dari hasil penelitian ini dilakukan pemeriksaan fungsi keseimbangan dengan menggunakan tes Romberg dan tandem Romberg. Pada tes Romberg ditemukan hasil negatif pada seluruh penderita tuberkulosis dengan pengobatan kategori 1 (22; 78,5\%). Sedangkan pada penderita tuberkulosis paru kategori 2 didapati 7 orang $(53,8 \%)$ dengan hasil tes Romberg positif. Hubungan ini terlihat bermakna pada hasil tes Fisher's Exact dengan nilai $p=0,000$. Sama dengan pemeriksaan tes tandem Romberg, hasil negatif didapati pada seluruh penderita tuberkulosis paru dengan pengobatan kategori 1 (22; $91,7 \%)$. Sedangkan pada penderita tuberkulosis paru kategori 2 didapati 11 orang $(100.0 \%)$ dengan hasil tes tandem Romberg positif. Hubungan ini terlihat bermakna pada hasil tes Fisher Exact dengan nilai p=0,000. Penelitian lain menemukan bahwa gangguan dari pemberian obat-obatan golongan aminoglikosida adalah gangguan vestibular yang terjadi pada seluruh sampelnya yaitu sebanyak 103 orang dan hanya 3 orang (2,9\%) yang mengeluhkan gangguan pendengaran dengan hasil audiometri yang meningkat sesuai dengan umur penderita. ${ }^{7}$

Tes Romberg dan tandem Romberg digunakan untuk menilai fungsi keseimbangan. Tetapi kedua tes ini mempunyai sensitivitas yang tidak terlalu tinggi untuk menilai kelainan (49-60\%). Hal ini disebabkan oleh daya kompensasi pada gangguan vestibular. Namun pemeriksaan ini cukup efektif untuk penilaian awal dalam menentukan adanya gangguan keseimbangan karena mempunyai spesivisitas yang tinggi terhadap gangguan keseimbangan yaitu sebesar 95\%. ${ }^{21}$ Secara teori, gangguan keseimbangan ini mungkin diakibatkan oleh obat-obatan golongan aminoglikosida, terutama streptomisin yang lebih bersifat vestibulotoksik dibandingkan dengan kokleotoksik. Hal ini disebabkan streptomisin dapat menyerang sel rambut pada organ vestibular dan dengan cepat streptomisin dapat menyerang dark cell pada organ vestibular. $^{22}$

Pada penelitian ini, rerata ambang dengar penderita tuberkulosis paru kategori 1 mempunyai nilai yang paling tinggi pada frekuensi $250 \mathrm{~Hz}$ yaitu sebesar 22,50 dB sedangkan nilai yang paling rendah berada pada frekuensi $8000 \mathrm{~Hz}$ yaitu sebesar 13,64 dB. Pada penderita tuberkulosis kategori 2 sesuai dengan distribusi sebelumnya mempunyai nilai yang paling tinggi pada frekuensi $8000 \mathrm{~Hz}$ yaitu sebesar $31,54 \mathrm{~dB}$ dan terendah pada frekuensi $1000 \mathrm{~Hz}$ yaitu sebesar 22,69 dB. Dari hasil $t$ test, hanya ditemukan perbedaan ambang dengar yang 
bermakna pada frekuensi $8000 \mathrm{~Hz}$ (nilai $\mathrm{p}=0$,006). Hal tersebut sesuai dengan penelitian sebelumnya, gangguan pendengaran lebih sering terjadi pada frekuensi tinggi $(88 \%)$. Peningkatan ambang dengar secara signifikan pada frekuensi tinggi dibandingkan dengan frekuensi rendah (nilai $\mathrm{p}<0,01$ ). Penelitian lain juga melaporkan gangguan pendengaran yang terjadi pada penderita tuberkulosis dengan penggunaan obat-obatan aminoglikosida lebih banyak pada frekuensi tinggi dibandingkan dengan frekuensi rendah. 1,6,20,23

Kerusakan pada frekuensi tinggi yang terjadi secara bilateral ini diakibatkan oleh proses degenerasi secara fisiologis pada koklea normal yang memperberat kerusakan akibat pemberian obat-obatan ototoksik secara sistemik. Telah diketahui bahwa proses ototoksik yang diakibatkan oleh obat-obatan golongan aminoglokosida disebabkan adanya stres oksidatif. Kompleks aminoglikosida-besi dapat berpotensi menghasilkan ROS yang menginduksi kerusakan pada sel rambut telinga dalam. Proses degenerasi yang terjadi pada sel rambut telinga dalam secara fisiologis dapat memperberat keadaan tersebut. ${ }^{24}$ Proses degenerasi terjadi dimulai pada daerah basal koklea dan berlanjut ke daerah apeks. Penelitian Sha et al, 25 juga mengatakan bahwa sel rambut pada daerah basal, tempat penerimaan frekuensi tinggi, lebih sensitif terhadap keadaan-keadaan yang merusak daripada sel rambut daerah apeks, tempat penerimaan frekuensi rendah. Sesuai dengan penelitian ini, penurunan ambang dengar dijumpai bilateral pada frekuensi tinggi dan tidak dijumpai perbedaan yang signifikan antara ambang dengar kanan dan kiri. ${ }^{24,25}$

Penelitian ini menemukan hubungan yang signifikan gangguan pendengaran (nilai $\mathrm{p}=0,043$ ) dan fungsi keseimbangan (nilai $p=0,000$ ) antara penderita tuberkulosis dengan pengobatan kategori 1 dan kategori 2. Namun, perlu dilakukan penelitian lanjutan dengan desain longitudinal untuk mengetahui hubungan obat-obatan tuberkulosis baik itu golongan aminoglikosida, isoniazid ataupun ethambutol dengan fungsi pendengaran dan keseimbangan dalam jumlah sampel yang lebih besar dan dalam waktu pemeriksaan yang lebih lama.

\section{Kesimpulan}

Penderita tuberkulosis kategori 2 mempunyai angka gangguan pendengaran dan keseimbangan lebih tinggi dibandingkan dengan penderita tuberkulosis kategori 1 dengan hubungan yang signifikan.

\section{Ucapan Terima Kasih}

Kami mengucapkan terima kasih kepada Ketua Departemen THT-KL RSUP H. Adam Malik, Prof. Dr. dr. Abd. Rachman Saragih, SpTHT-KL(K), Ketua Departemen Pulmonologi RSUP H. Adam Malik Prof. dr. Luhur Soeroso, Sp.P(K), dan PT Kasoem Hearing
Centre yang turut berkontribusi dalam penyelesaian penelitian ini.

\section{Daftar Pustaka}

1. Vasconcelos KA, Kritski Al, Netto AR, Frota S. Audiometric evaluation of patients treated for pulmonary tuberculosis. Jornal Brasileiro de Pneumologia. 2012; 38(1): 81-87.

2. Aditama TY, Kamso S, Basri C, Surya A. Pedoman nasional penanggulangan tuberkulosis. Edisi 2. Jakarta: Departemen Kesehatan Republik Indonesia; 2007.

3. World Health Organization. Global tuberculosis control : WHO Report 2011. France: WHO Press; 2011. WHO/HTM/TB/2011.16.

4. Soemantri S, Ariawan I. Analisis lanjut survei prevalensi tuberkulosis 2004 investigasi faktor lingkungan dan faktor resiko tuberkulosis Indonesia. Jakarta: Badan Penelitian dan Pengembangan Kesehatan, Departemen KesehatanRepublik Indonesia dan WHO Indonesia; 2004.

5. Rasmin M, Yunus F, Priyanti ZS, Melintira I, Puspitorini D, Rahayu S, dkk. Profil penderita tuberkulosis paru di RS Persahabatan Januari- Juli 2005. Jurnal Respirologi Indonesia. 2006; 27 (1): 402-8.

6. Lima MLLT, Lessa F, Santos AMA, Medeiros Z. Hearing impairment in patients with tuberculosis from northeast brazil. Revista do Instituto de Medicina Tropical de São Paolo. 2006; 48 (2): 99-102.

7. Ahmed RM, Hannigan IP, Chan RC, Halmagyi GM. Gentamicin ototoxicity: a 23-year selected case series of 103 patients. The Medical Journal of Australia. 2012; 196: 701-4.

8. Altiparmak MR, Pamuk ON, Pamuk GE, Ataman R, Serdengecti K. Is isoniazid ototoxicity in patients undergoing hemodialysis?. Nephron Journal. 2002; 92: 478-80

9. Yerdelen D, Tan M. Ototoxicity probably due to isoniazis in a patient undergoing hemodialysis. Journal of Neurological Sciences. 2008; 25 (14): $51-4$.

10. Katijah KS, Anniah M, Precious MN. Ototoxic effects of tuberculosis treatment: how aware are patients. African Journal of Pharmacy and Pharmacology. 2009; 3 (8): 391-9.

11. Menzies D, Jahdali HA, Otaibi BA. Recent developments in treatment of latent tuberculosis infection. The Indian Journal of Medical Research. 2011; 133 (3): 257-66.

12. Donald PR, Marais BJ, Barry CE. Age and the epidemiology and pathogenesis of tuberculosis. The Lancet. 2010; 375: 1906-20.

13. Borgdorff MW, Nagelkerke NJD, Dye C, Nunn P. Gender and tuberculosis: a comparison of prevalence surveys with notification data to explore sex differences in case detection. The International Journal of Tuberculosis and Lung Disease. 2000; 4 (2): 123-32.

14. Diwan VK, Thorson A. Sex, gender and tuberculosis. The Lancet. 1999; 353:1000-1.

15. Rybak LP, Talaska AE, Schacht J. Drug-Induced Hearing Loss. In: Fay, R.R., Popper, A.N. (eds) Auditory Trauma Protection and Repair. $1^{\text {st }}$ ed. New York: Springer; 2008. p. 219-54.

16. Water TRVD, Staecker H. Otolaryngology, basic science and clinical review. $1^{\text {st }}$ Ed. New York: Medical Publisher, inc; 2007. p. 129-30

17. Gulbay BE, Gurkan OU, Yildiz OA, Onen ZP, Erkekol FO, Baccioglu A, et al. Side effect due to primary antituberculosis drugs during the initial phase of therapy in 1149 hospitalized patients for tuberculosis. Respiratory Medicine. 2006; 100 (10): 1834-942. 
18. East JE, Foweraker JE, Murgatroyd FD. Gentamicin induced ototoxicity during treatment of enterococcal endocarditis: resolution with substitution by netilmicin. Heart. 2005; 91: 1-2.

19. Javadi MR, Abtahi B, Gholami K, Moghadam BS, Tabarsi P, Salamzadeh $J$. The Incidence of Amikacin ototoxicity in multidrug-resistant tuberculosis patients. Iranian Journal of Pharmaceutical Research. 2011; 10(4): 5-911

20. Peloquin CA, Berning SE, Nitta AT, Simone PM, Goble M, Huitt GA, et al. Aminoglycoside toxicity: daily versus thrice-weekly dosing for treatment of Mycobacterial disease. Clinical Infections Disease: an official publication of the Infectios Disease. 2004; 38: 1538-44.

21. Filho PA, Maranhao ET, Silva MM, Lima MA. Rethinking the neurological examination I. Arquivos de Neuro-psiquiatria. 2011; 69 (6): 9548.
22. Cureoglu S, Schachern PA, Paparella MM. Effect of parenteral aminoglycoside administration on dark cells in the crista ampullaris. Archives of Otolaryngology-head \& Neck Surgery. 2003; 129: 626-8.

23. Duggal P, Malay S. Audiologic monitoring of multi-drug resistant tuberculosis patients on aminoglycoside treatment with long term followup. BMC Ear, Nose and Throat Disorder. 2007; 7 (5): 1-7.

24. American Academy of Audiology [homepage on the internet]. American Academy of Audiology Position Statement and Clinical Practice Guidelines: Ototoxicity Monitoring. United State of America: Am Academy of Audiology; 2009 (updates 2009 Oct; cited 2012 Feb 02). Available from: http://www.audiology.org.

25. Sha SH, Taylor R, Forge A, Schacht J. Differential vulnerability of basal and apical hair cell is based on intrinsic susceptibility to free radical. Hear Research. 2001; 155: 1-8. 